\title{
The regional costs of market size losses in a EU dismembering process
}

\section{Roberta Capello I Andrea Caragliu I Ugo Fratesi}

Politecnico di Milano, Architecture, Built Environment and Construction Engineering, piazza Leonardo da Vinci, 32, Milano, MI 20133, Italy

\section{Correspondence}

Andrea Caragliu, Politecnico di Milano, Architecture, Built Environment and Construction Engineering, piazza Leonardo da Vinci, 32, Milano, MI 20133, Italy.

Email: andrea.caragliu@polimi.it

JEL Classification: R11; R22

\begin{abstract}
The paper measures regional GDP growth losses that a smaller market size caused by the reintroduction of legal and administrative barriers would cause. We model augmented barriers in a Keynesian framework, pointing at four effects: a border effect, stronger for regions close to borders; an exposure effect, stronger for regions open to trade; a centrality effect, affecting areas close to the economic core; a demand concentration effect, stronger for regions close to large trading partners. By estimating border effects with data on EU NUTS 3 regions and simulating a general increase in barriers among EU countries, the four regional effects clearly emerge.
\end{abstract}

\section{KEYWORDS}

Brexit, market access, demand spillovers, border effects

\section{1 | INTRODUCTION}

The recent choice of the United Kingdom to leave the European Union has revamped the debate on the potential costs of Brexit for both the UK and for other EU member states. An empirical verification of the magnitude of such costs would implicitly confirm the relevance of the EU Common Market, thus minimizing the risk of a domino effect, with other countries in their turn receding from EU membership.

The sheer existence of economic losses due to leaving the EU is not criticized; such losses have been recently indirectly measured, by showing that GDP losses affect EU member states because of an imperfect implementation of the Single Market. Based on the celebrated Cecchini report (Cecchini, Jacquemin, Robinson, \& Catinat, 1988), several studies measured the costs of the incomplete Single Market, which on average are found to be relevant, with estimates ranging from 2.2\% (Ilzkovitz, Dierx, Kovacs, \& Sousa, 2007) to 12\% of EU GDP (Campos, Corricelli, \& Moretti, 2014), depending on the methodology used and the types of barriers analysed. In Dunne (2015) the losses of non-Europe were assessed at 1.6 trillion Euros, with, among their many determinants, 400 billion Euros being due to the absence of a joint digital market, and 615 billion Euros due to the absence of a single market for consumers and citizens. Along the same lines, the removal of barriers in the area of e-commerce alone would engender benefits equal to 748 billion Euros (Godel, Harms, Jones, \& Mantovani, 2016). More recently, the cost of existing legal and 
administrative barriers has been estimated as 9\% of total GDP in border regions (Camagni, Capello, Caragliu, \& Toppeta, 2017).

This paper contributes to the debate on the costs of EU dismembering by focusing on a specific effect that the EU disintegration would engender, namely, the missed access to a large and integrated market for intermediate and final goods. We leave aside all other macroeconomic effects that the EU dismembering would cause, thereby focusing on pure demand-side effects through the loss of international trade. The collapse of the Single Market would reintroduce a high number of legal and administrative barriers among EU countries, hampering international trade and the free movement of goods, and theoretically causing a slowdown in economic growth.

More in detail, the paper measures the spatial distribution of GDP growth losses due to the missed access to a large and integrated market. Ex ante, it is difficult to speculate whether the GDP slowdown due to the dismembering of the Single Market would be higher in rich areas, where most economic activities are located, or in weaker regions, suffering from the loss of demand spillovers due to a generally more dynamic national economy.

In order to reach this goal, we first introduce a theoretical model, based on a Keynesian framework, and describe the impact of legal and administrative barriers on trade. Such barriers are expected to hamper demand spillovers that regions receive as a consequence of being part of the Single Market. An increase in legal and administrative barriers due to the EU dismembering is expected to engender four spatial effects: a border effect, capturing the proximity of the region to a border, an exposure effect, measuring the dependence of the regional economy from international trade, a demand concentration effect, measuring the distance of regions to significant (large) trading partners in which income is concentrated, and a centrality effect, capturing the pure physical proximity of the regional economy to trade partners.

To empirically detect whether our theoretical model finds empirical validation, we estimate a regional growth model for all European NUTS 3 regions, in which, among the traditional explicative and control variables, regional growth is made dependent on demand spillovers, measured as the GDP of neighbouring regions, weighted by physical distance and by the degree of openness of the region. The barrier effect is estimated by measuring how much demand spillovers change their weight in explaining regional growth when a legal and administrative barrier is present. As we shall see, econometric estimates show that the existing legal and administrative barriers between EU countries do generate demand spillover losses, which translate into lower GDP growth.

The last step of this empirical exercise is to simulate a situation in which barriers strongly increase among all EU countries. This simulation illustrates that the loss of GDP due to a reduction in demand spillovers decreases with different intensity in different regions, with a remarkable spatial heterogeneity; the four effects theorized by the model clearly show up.

The structure of the paper is as follows. In the next section, a brief review of the literature discussing the theoretical advantages of Single Market is presented; were the Single Market to collapse, such integration advantages would turn into costs (i.e. missed growth opportunities). Section 3 presents our logical approach by setting out a theoretical model, based on a Keynesian framework, which models the impact of the increase in trade barriers on regional GDP growth. In Section 4 the model is empirically tested, and the data are discussed, with a particular focus on how we measure legal and administrative barriers. Section 5 presents the simulation and the empirical results. Section 6 concludes.

\section{2 | ADVANTAGES OF MARKET INTEGRATION: REGIONAL EFFECTS}

International economics has devoted many efforts to demonstrate the advantages gained in trade through integration. ${ }^{1}$ One branch of international economics dedicated to such effort is customs unions theory. This literature emphasizes how the creation of a customs union entails the abolition of economic and institutional barriers to

${ }^{1}$ On the effects of creation of the European Common Market see Thirlwall (1974), Balassa (1975) and Scitovski (1958). On those of the creation of the Single Market see Cecchini et al. (1988), Quévit (1992) and Camagni (1992). 
international trade through the elimination of customs tariffs and duties, the harmonization of technical standards in production, the adoption of rules on the (possibly, certified) quality of products, on their safety and transport, the abolition of disparities in the indirect taxation of consumption goods, and the adoption of common regulations of capital markets.

Custom unions eventually cause an expansion of the final markets for goods and services with the emergence of large integrated markets, bearing substantial advantages (Capello, 2016):

- an increase in competition. Each region purchases from the most efficient supplier in the European market;

- greater economies of scale in manufacturing due to larger market size;

- the stimulation of trade in final and intermediate goods because local markets can be replaced by newly accessible more distant ones;

- increased investment prompted by forecasts of greater competition: an effect which comes about even before the creation of single market, as a result of market expectations to which firms quickly adjust;

- demand for a greater variety of goods because of increased per capita income (income effect);

- a shift of demand towards goods produced with more efficient techniques guaranteeing lower prices for the same quality; and

- technology and knowledge transfers from strong to weak regions.

All these channels are expected to have different spatial impacts. With the exception of the last effect, all such channels tend to favour rich and more advanced regions. The latter in fact own the financial, productive and knowledge resources needed for coping with increased competition, for meeting a more diversified demand schedule, for exploiting increased scale economies, and for making substantial, focused, and timely investment as the creation of a Single Market proceeds.

The only source of advantages in the integration process that seems to favour lagging regions is the expected technology transfer from the "centre" to the "periphery." However, this is clearly a rather complex process, which requires substantial local know-how (not necessarily available in weaker regions) to enhance the exploitation of new technologies for reaching local growth targets. These expectations have been indirectly verified in the first period of the Single Market, when regional disparities increased, suggesting that advantages were concentrating in richer areas (CEC, 2001; Petrakos, Rodríguez-Pose, \& Rovolis, 2005).

Another interesting spatially differentiated effect of the Single Market has been observed when formerly socialist countries entered the EU. As the result of this new (2004-2007) wave of enlargement, intra-national disparities increased because of the centripetal forces of economic development in the metropolitan and core areas of these Countries. Economic activity in these countries, in fact, concentrated in areas closer to the old members of the EU, as demonstrated in many studies (Bachtler \& Downes, 1999; Petrakos, 2000; Resmini, 2007; Traistaru, Nijkamp, \& Resmini, 2003).

Regional disparities increased as a result of economic integration also at the micro-territorial level. This is for instance the case of spatial disparities between strong and weak areas within countries after the creation of the single European market in 1993; in the Italian case, for instance, positive effects were mostly registered in large cities such as Milan, Rome and Naples while small and medium cities benefited much less from the institutional framework (Camagni \& Pompili, 1990; Capello, 2002).

The exposure of lagging regions to the windfalls of strong competition within single markets has been thoroughly analysed in the new economic geography (NEG) literature, which discusses at length the clash between centripetal and centrifugal forces in shaping the spatial distribution of resources. NEG provides several interesting results that are useful to properly frame our own theoretical setting. One channel that may potentially be conducive to losses for lagging regions in case of more integrated markets is discussed in Puga (2002), which shows that increased market integration could expose lagging regions to fiercer competition. Besides, Breinlich (2006) and Head and Mayer (2006) 
provide evidence, based on EU regions, on the empirical relationship between nominal wages and market access: more integrated markets are thus expected to be conducive to higher nominal wages (and, by the same token, reduced market integration such as that following the EU dismembering, is expected to cause a generalized increase in nominal salaries).

The natural question stemming from this literature is whether we could expect specular (i.e., negative) effects as a consequence of a potential European dismembering process. Exactly as the creation of the single market has generated positive and spatially heterogeneous effects, its dismembering is expected to slow down regional growth; moreover, these losses are expected to be spatially heterogeneous.

Various effects of the dismembering process are logically to be foreseen. Losses may be stronger in:

- advanced regions, where advanced manufacturing and services activities are concentrated;

- regions closer to the institutional borders, that would be particularly hit by augmenting legal and administrative barriers that would drastically reduce the size of border regions' local markets; and

- less advanced regions, that would suffer from the loss of a pull effect generated by growing national economies.

The existing literature on Brexit, and more in general on the potential consequences of EU dismembering (Dhingra, Ottaviano, Sampson, \& Van Reenen, 2016a; Dhingra, Ottaviano, Sampson, \& Van Reenen, 2016b; Jensen \& Snaith, 2016; van Reenen, 2016) does not explicitly take the regional dimension into account. Neither is this dimension accounted for in the literature on the costs of non-Europe (Ilzkovitz et al., 2007; Boltho \& Eichengreen, 2008; Campos et al., 2014). This literature agrees on the fact that many international barriers still exist among European countries; that these barriers cut across different fields; that they hamper the full achievement of integration advantages. However, none of the aforementioned works is interested in the regional dimension of these effects. ${ }^{2}$

One of the major limits generated by the presence of barriers, in particular by legal and administrative ones, that are more directly linked to trade, is the limitation of market size. In its turn, this causes a decrease in scale economies for firms, a loss of competition, and, because local markets become sheltered, a decrease in average productivity. In what follows, the main emphasis of our approach is on a specific effect that EU dismembering would cause, namely, the loss of a large and integrated market for intermediate and final goods. This would come with the reintroduction of duties and tariffs, while also increasing differences in legal and administrative procedures.

We focus on this issue because this is arguably most directly affected by EU dismembering. In fact, effects may be felt even in the very short run, through the rational expectations channel. In order to make the case for the relevance of this channel, in the next section we model in a Keynesian framework the loss of market size due to higher legal and administrative barriers and the ensuing GDP growth slowdown. The model is meant to formalize the cause-effect mechanism that paves the way for the empirical application in Section 5.

\section{I MODELLING THE IMPACT OF NEW INSTITUTIONAL BARRIERS ON REGIONAL GROWTH}

In order to assess the regional impact of EU dismembering within a demand-side framework, we can think of the impact of an increase of new barriers to trade between regions on regional growth. Let us start by thinking of exports of region $i\left(X_{i}\right)$ as being by definition identical to the sum of the imports of all other trading partner regions $j$ from region $i\left(M_{j i}\right)$ :

$$
X_{i}=\sum_{j} X_{i j}=\sum_{j} M_{j i}
$$

\footnotetext{
${ }^{2} \mathrm{~A}$ recent study has been run at regional level on the 'quantification of the costs of legal and administrative barriers for land border regions'. See Camagni et al. (2017).
} 
Imports of the various trading partner regions $j$ depend on their income levels and on their propensity to import goods and services from other regions. Moreover, total imports are the sum of the imports from all trading partners, each of them having a different share of these imports. Let us define $m_{j}$ as the propensity to import of region $j$, and $m_{j k}$ as the propensity of region $j$ to import from a generic region $k$. Thus, total imports of region $j\left(M_{j}\right)$ are defined as:

$$
M_{j}=m_{j} Y_{j}=\sum_{k} M_{j k}=\sum_{k} m_{j k} Y_{j}
$$

Let us now assume, consistently with the gravity literature, that any region $j$ tends to import more from regions that are larger (because they have a larger variety of goods and services to buy); from regions that are closer (because there are lower transport costs in buying their goods), and from regions specialized in exporting sectors (because they account for a larger share of trade). This can be analytically represented as follows:

$$
m_{j k}=\vartheta_{k} \frac{Y_{k}}{d_{j k}}
$$

where $d_{j k}$ is distance between regions $k$ and $j, Y_{k}$ is the economic size of the trade partner region $k$; and $\vartheta_{k}$ measures the specialization of region $k$ in exporting sectors or, in other words, the exposure of the local economy to international trade.

Imports of the generic trading partner region $j$ from region $i$ are therefore equal to:

$$
M_{j i}=m_{j i} Y_{j}=\vartheta_{i} \frac{Y_{i}}{d_{i j}} Y_{j}
$$

Total exports of region $i$ are obtained by plugging Equation 4 in Equation 1:

$$
X_{i}=\sum_{j} \vartheta_{i} \frac{Y_{i}}{d_{i j}} Y_{j}
$$

Let us now assume, consistently with an extended version of a Keynesian macroeconomic model, that region i's income depends on several endogenous factors as well as on its ability to export, which is reflected in its degree of openness. In particular, let us assume that exports impact income through the $\mu_{i}$ multiplier; then we can restate regional income as a function of endogenous factors (at regional and national level) $\left(G_{i}\right)$ and regional exports as defined in Equation 5:

$$
Y_{i}=Z_{i}+\mu_{i} X_{i}=Z_{i}+\mu_{i} \sum_{j} \vartheta_{i} \frac{Y_{i}}{d_{i j}} Y_{j}=Z_{i}+\mu_{i} \vartheta_{i} Y_{i} \sum j \frac{Y_{j}}{d_{i j}}
$$

where $Z_{i}$ represents the endogenous component of a region's income. If a barrier arises between region $i$ and any of its trading partners $j$, this hampers trade between the two regions by a factor $b_{i j}$. This barrier can be assumed to be specific to the couples of regions; in other words, this allows to model barriers arising specifically only between specific region couples and not others. In the case of this paper, we assume that as a consequence of the EU dismembering, higher barriers will arise between regions belonging to EU countries.

When a new barrier arises, at time $t+1$, Equation 5 modifies and the new amount of exports from region $i$ towards its trading partner regions decreases to:

$$
X_{i}=\Sigma_{j}\left(1-b_{i j}\right) \vartheta_{i} \frac{Y_{i}}{d_{i j}} Y_{j}
$$

The impact of the increased trade barrier on regional growth between times $t$ and $t+1$ is simply proportional to the ratio of the difference between the two trade-induced parts of income and the initial income level. Regional 
income growth $\left(y_{i}\right)$ still depends on the growth of all other, especially endogenous, aspects $\left(z_{i}\right)$, but faces a decrease because of the new barrier $\left(\mu_{i} \vartheta_{i} \sum_{j} b_{i j} \frac{Y_{j}}{d_{i j}}\right)$ as follows:

$$
y_{i}=\frac{Y_{i}^{t+1}-Y_{i}^{t}}{Y_{i}^{t}}=\sigma_{i} z_{i}-\mu_{i} \vartheta_{i} \sum_{j} b_{i j} \frac{Y_{j}}{d_{i j}} .
$$

Equation 8 can be econometrically estimated to detect the impact of the $b$ barrier.

In order to better visualize the implications of this model, we can graphically show the impact of exports towards other regions $j$ on region i's income. This is basically a demand spillover, which from Equation 6 is equal to:

$$
\text { demand_spill } l_{i}=\mu_{i} \vartheta_{i} Y_{i} \sum_{j} \frac{Y_{j}}{d_{i j}} \text {. }
$$

In order to simplify this graphical representation, we assume that all trading partners $j$ have the same size $\left(Y_{j}=\bar{Y}\right)$. In this case, the impact of demand spillovers on region i's income decreases with distance. This demand spillover can be represented with an asymptotically decreasing line, as in Figure 1.

Figure 2 represents demand spillovers when we assume that an obstacle arises between region $i$ and all trading partner regions $j$. Once again for the sake of clarity this obstacle is assumed to be the same for all regions $\left(b_{i j}=\bar{b}\right)$; as a consequence, demand spillovers decrease by the same amount for all trading partners. In Figure 2, this in represented by a decrease in the spillover from the dotted line (representing demand spillovers without the obstacle) to the dashed line (representing demand spillovers in the presence of the obstacle), where all values of the lower line are a fixed proportion $(1-b)$ of the values of the upper line.

The case in which the obstacle arises only for the trading partners which are above a given threshold distance $\bar{d}$ from region $i$ is more interesting. This is the case in which, for instance, the obstacle only arises in regions belonging to different countries, and $\bar{d}$ is the distance between region $i$ and the border. In this case, the demand spillovers line decreases only above a threshold distance, and its functional form resembles the shape of the black continuous line in Figure 2.

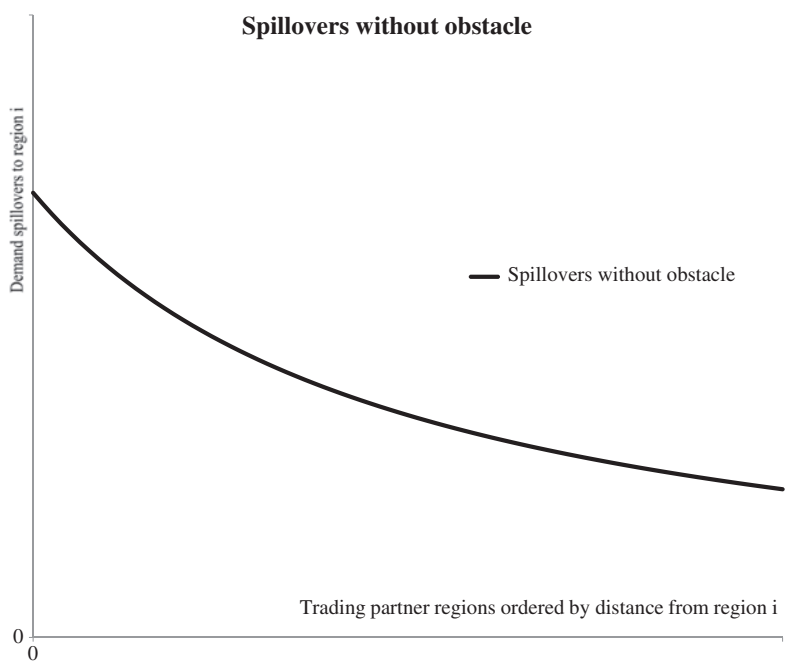

FIGURE 1 Demand spillovers from other regions in the absence of obstacles 


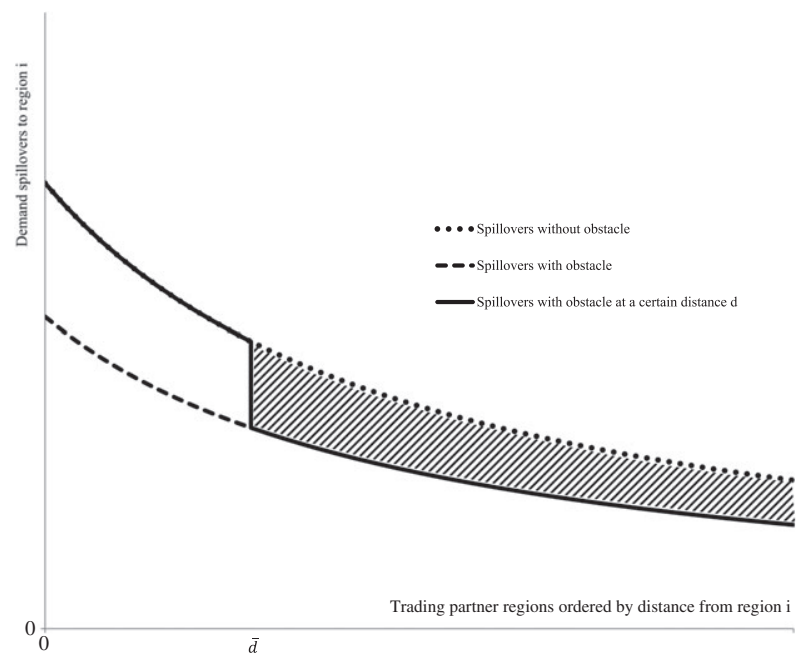

FIGURE 2 Loss of GDP growth due to a decrease in demand spillovers as a result of a barrier's increase

Figure 2 also allows to measure the loss of income due to the presence of the new barrier. This loss is equal to the integral of the difference between the two spillovers curves, with and without the obstacle, beyond distance $\bar{d}$. Thus, Figure 2 illustrates why regions closer to the border are expected to suffer more from the augmented barrier.

There are parameters in the model which influence the way in which arising barriers can hamper regional growth through demand spillover's decrease between regions. Each parameter can be linked to an effect. In particular, the effects of arising barriers are expected to be higher when:

1. the distance of the region from the border is lower (parameter $d$ in the model). In fact, regions closer to the border are also closer to regions in other countries, thereby suffering more from the new barrier. This effect can be defined a border effect;

2. the openness of a regional economy is higher, depending on their specialization in open exporting sectors (parameter $\vartheta_{i}$ in the model). The income of regions open to trade, in fact, depends more heavily on trade itself; therefore, they will suffer more from the increase in the barrier between them and their trading partners. This can be called an exposure effect;

3. accessibility of the local area from other potentially trading partners is higher. Regions closer to the geographical centre of Europe (i.e. having on average a smaller parameter $d_{i j}$ ) will suffer more from the presence of new barriers, as they gained more in the periods of increased integration. This effect can be termed centrality effect; and

4. the distance of a regional economy to significant trading partners (that are comparatively large in economic terms) is lower (parameter $Y_{j}$ in the model). Larger trading partners are in fact expected to import, ceteris paribus, more goods and services with respect to smaller ones. This can be defined a demand concentration effect.

In the European case, the two last situations are normally present for the same regions, as the European economic core, that is, the area with maximum agglomeration of economic activities, overlaps with the geographical core, namely, the area with higher centrality and accessibility. As a consequence, regions closer to the centre of Europe will simultaneously be more accessible and closer to large trading partners.

Two effects, acting in opposite directions, cannot be considered in this framework. The first effect is a possible export diversion of a regional economy which, facing increased barriers in exporting to the traditional destination 
market, will search for other (possibly further) export markets. Significant trade diversion effects would imply an overestimation of the impacts discussed in this paper.

The second effect is the indirect effect going from a region to another through third-party regions. It is in fact possible that, facing increased barriers between the target region and its trading partner, also other regions, trading partners of the latter, would decrease their demand from the first region due to reduced income and to decreased intra-industry trade. The presence of this second effect may potentially cause a downward bias of the results (underestimation). Since we cannot measure these two effects, that act in opposite directions, we have no clue about the real extent of the bias in the empirical results, if any.

\section{4 | MARKET SIZE, GDP GROWTH AND LEGAL AND ADMINISTRATIVE BARRIERS: AN EMPIRICAL ESTIMATION}

\section{1 | Empirical methodology}

This section provides and empirical validation of the model discussed in Section 3. Equation 8 can be rewritten in a reduced form as:

$$
y_{T-t}=\alpha+\beta Z+\gamma S+\varepsilon
$$

where $y_{T-t}$ measures gross value added growth between $t$ and $T$ (in this case, respectively equal to 2008 and $2013^{3}$ ).

This is regressed against a matrix $Z$ of regional growth factors, including a NUTS 3 region's settlement structure, its urbanization economies, accessibility, saving propensity, level of trust, human capital, intensity of knowledge and product innovation activities, and spare productive capacity, as suggested by the main theoretical paradigms behind regional growth theory, namely the theory of bounded rationality and decision-making under conditions of uncertainty (Malmgren, 1961; Simon, 1972) and their application to industrial innovation (Dosi, 1982; Nelson \& Winter, 1982) and the cognitive approach to district economies and synergies, which comprises the Italian school (Becattini, 1990), the French "proximity" approach (Gilly \& Torre, 2000), the GREMI approach to local innovative environments (Camagni, 1991; Camagni \& Maillat, 2006), and Michael Storper's concept of "untraded interdependencies" (Storper, 1995), highlighting agglomeration economies, innovation, knowledge and cultural aspects, in the form of territorial identity (Capello, 2017) as sources of competitiveness.

Matrix $S$ measures the demand spillovers' effects due to the presence of a barrier $B$, estimating the difference between demand spillover effects ( $W Y^{*}$ Openness) and the same effects when a barrier is present (WY* Openness * $B$ ):

$$
S=\phi\left(W Y^{*} \text { Openness }\right)-\Psi\left(W Y^{*} \text { Openness }^{*} B\right)
$$

where Equation 11, translating Equation 7 in empirical terms, assumes, as in the theoretical model, that demand spillovers are mediated by a region's degree of openness $\left(\vartheta_{i}\right.$ in the theoretical model), by distance $(W)$ and by the economic size of the trade partners $(Y)$. In its turn, $W Y$ is defined as:

$$
W Y=\sum_{J=1, j \neq i}^{n} W_{i j} Y j
$$

where $w_{i j}$ is an entry in the geographical distance matrix $W$, while $i$ and $j$ indicate two generic regions. In this paper, the $W$ matrix is based on a standard great circle distance between the regions' centroids.

\footnotetext{
${ }^{3}$ Regressions have been run on the 2006-2013 period as a robustness check, without significantly affecting our findings. The choice of the 2008-2013 period for measuring the dependent variable is motivated by the aim not to include the last pre-crisis years, which would significantly bias the picture of regional growth in Europe.
} 
As for the degree of openness, the second component of Equation 11, it formalizes the degree to which each region is potentially exposed to the positive effect of the existence of a wider external market. In this paper, in the absence of accurate interregional trade at this very detailed spatial level, we proxy openness with the specialization in manufacturing activities; ${ }^{4}$ given the limited size of the spatial units (European NUTS 3 regions) here analysed, it is reasonable to assume that most manufactured goods will not be consumed locally and will therefore be shipped at least beyond regional borders. While this choice clearly presents the potential limitation of underestimating trade in services ${ }^{5}$ and especially openness for regions specialized in advanced services, which tend to be the most important global players (Capello \& Fratesi, 2013), it must be recognized that a large share of high value added services still tend to be consumed locally despite the undeniable trend of internationalization in their consumption (Roberts, 1989; WTO, 2016). ${ }^{6}$

Notice that estimating $\gamma$ is the direct consequence of the existence of the parameter $\mu_{i}$ in Equation 8. This parameter, estimated as such, incorporates all four effects which are presented at the end of the previous section and gives a quantification of the magnitude of the aggregate effect assuming the presence of the four impedances of accessibility, distance from large regions, openness to trade and presence of barriers through the borders.

Lastly, a word must be spent on the $B$ matrix in Equation 11. Within all possible (cultural, linguistic, social) international barriers we could discuss, our choice was to focus on legal and administrative barriers, which are expected to influence trade flows more directly. Were these barriers to increase as a consequence of EU dismembering, they would cause a reduction in the free circulation of freight, through higher tariffs on international goods shipments and through price differences, menu costs, and reinstated currency risk (Obstfeld \& Rogoff, 2000).

For this reason, $B$ is a bilateral matrix measuring the intensity of legal and administrative barriers between regions' couples, measured through the perception that people have of such barriers. ${ }^{7}$ This is a very broad indicator, that does not delve into a detailed definition of such barriers. While this may provide an imperfect picture of the intensity of these barriers, it certainly offers a broad assessment that would be impossible were more detailed indicators chosen. Moreover, in a simulation exercises, having the perception that people have of such barriers as a variable can be useful to interpret expectations about the problems caused by augmented legal and administrative barriers; without waiting for barriers to actually increase, effects will be felt simply because of the expectations that people form about the future increase in these barriers.

\subsection{Measuring the intensity of legal barriers in European regions}

The data base assembled for the empirical verification of the framework discussed above includes the regional growth factors listed in subsection 4.1. Table 1 provides a detailed account of the main indicators, data and sources for each control variable of the $Z$ endogenous factors.

A more detailed account of the way legal barriers have been measured is instead needed. Among the many possible ways to capture the intensity of interregional legal barrier, we resorted to the use of survey data. In particular, the intensity of legal and administrative barriers is captured by the average regional score in the question "Thinking about the cooperation between your Country and [COUNTRY FROM PROGRAMME XX], to what extent are legal or administrative differences a problem?" asked within the Eurobarometer 422 flash survey on interregional

\footnotetext{
${ }^{4}$ The issue of trade data availability at the regional level is discussed in Brakman and Van Marrewijk (2017).

${ }^{5}$ Services have been increasing their share of world trade since at least 1985 (Capello, Fratesi, \& Resmini, 2011).

${ }^{6}$ Empirically, manufacturing still appears a much better proxy for trade openness, as also evidenced by the much higher relevance of manufactured goods trade over trade in commercial services (WTO, 2016). In 2015, the last year with full WTO data available, merchandise trade outweighed trade in commercial services by a factor of 4.57. Technically, this potential bias should translate into a low impact of raising legal barriers as a consequence of the EU dismembering in areas specialized in internationally open advanced services, such as South-Eastern England. Fortunately, results demonstrate this is not the case.

${ }^{7}$ See subsection 4.2 for a detailed description of the way in which matrix $B$ is built.
} 
TABLE 1 Indicators, data and sources

\begin{tabular}{|c|c|c|c|c|}
\hline Category & Indicator & Data & Source & Year \\
\hline Dependent variable & $\begin{array}{l}\text { Regional } \\
\text { growth }\end{array}$ & Growth of gross value added & EUROSTAT & 2008-2013 \\
\hline \multirow[t]{2}{*}{$\begin{array}{l}\text { Knowledge and } \\
\text { innovation }\end{array}$} & Knowledge & $\begin{array}{l}\text { Number of patent applications to the European patent } \\
\text { office (EPO) per million inhabitants }\end{array}$ & EUROSTAT & 2006 \\
\hline & $\begin{array}{l}\text { Product } \\
\quad \text { innovation }\end{array}$ & $\begin{array}{l}\text { Number of trademarks applications to the EPO per } \\
\text { million inhabitants }\end{array}$ & EUROSTAT & 2006 \\
\hline \multirow{3}{*}{$\begin{array}{l}\text { Knowledge and } \\
\text { innovation } \\
\text { generating assets }\end{array}$} & Accessibility & $\begin{array}{l}\text { Location quotient of multimodal accessibility } \\
\text { standardized with EU } 27 \text { mean }=1\end{array}$ & ESPON & 2006 \\
\hline & $\begin{array}{r}\text { Urbanization } \\
\text { economies }\end{array}$ & Population density & EUROSTAT & 2006 \\
\hline & $\begin{array}{l}\text { Human } \\
\text { capital }\end{array}$ & $\begin{array}{l}\text { Share of working age population with ISCED } 5 \text { and } 6 \\
\text { degrees. }\end{array}$ & EUROSTAT & 2006 \\
\hline \multirow[t]{2}{*}{$\begin{array}{l}\text { Regional industrial } \\
\text { structure }\end{array}$} & $\begin{array}{l}\text { Industrial } \\
\text { activities }\end{array}$ & Share of GVA in manufacturing over total GVA & EUROSTAT & 2006 \\
\hline & $\begin{array}{l}\text { Productive } \\
\text { capacity }\end{array}$ & $\begin{array}{l}\text { Ratio between employed persons and working age } \\
(25-64) \text { population }\end{array}$ & EUROSTAT & 2006 \\
\hline $\begin{array}{l}\text { Long run local } \\
\text { economic } \\
\text { resources }\end{array}$ & $\begin{array}{l}\text { Saving } \\
\text { propensity }\end{array}$ & $\begin{array}{l}\text { Share of persons that in the European value study } \\
\text { consider it important or very important to teach } \\
\text { children the importance of thrift }\end{array}$ & $\begin{array}{l}\text { European } \\
\text { value } \\
\text { study }\end{array}$ & 2008-2009 \\
\hline $\begin{array}{l}\text { Regional settlement } \\
\text { structure }\end{array}$ & $\begin{array}{l}\text { Settlement } \\
\text { structure }\end{array}$ & $\begin{array}{l}\text { Dummy identifying agglomerated, urban and rural } \\
\text { regions }^{\mathrm{b}}\end{array}$ & $\begin{array}{l}\text { ESPON } \\
\text { project } \\
1.1 .1\end{array}$ & 2005 \\
\hline Intangible assets & Trust & $\begin{array}{l}\text { Share of EVS respondents stating that they trust fellow } \\
\text { citizens } s^{c}\end{array}$ & $\begin{array}{l}\text { European } \\
\text { value } \\
\text { study }\end{array}$ & 2008-2009 \\
\hline
\end{tabular}

Source: Capello et al. (2016), own elaboration.

Notes: "Share of respondents "Important" or "Very Important" to the EVS question "Here is a list of qualities which children can be encouraged to learn at home. Which, if any, do you consider to be especially important? Please choose up to five": the importance of thrift"

bagglomerated regions are defined as those regions hosting a city of more than 300,000 inhabitants and a population density higher than 300 inhabitants $/ \mathrm{km}$ sq. or with a population density between 150- and 300 inhabitants $/ \mathrm{km}$ sq. Urban regions are defined as hosting a city between 150,000 and 300,000 inhabitants and a population density between 150 and 300 inhabitants/km sq. (or a smaller population density - between 100 and 150 inh./km but with a bigger centre, with more than 300,000 inh.) or a population density between 100 and 150 inh./kms sq. Finally, rural regions are those areas with a population density lower than 100 inh./ sq. km. and a centre with more than 125,000 inh., or a population density lower than 100 inh./sq. kms. with a centre smaller than 125,000 inhabitants. See also Capello and Chizzolini (2008).

"Share of respondents to the following questions have been applied: "Most people can be trusted" to the EVS question "Generally speaking, would you say that most people can be trusted or that you can't be too careful in dealing with people?"

cooperation. Possible answers to this question range from "A major problem" (encoded as 1) through "A minor problem (2)" to "Not a problem at all (encoded as 3)." Questionnaires have been administered in September 2015 and include a grand total of 40,619 individual observations distributed across the EU28 countries plus Norway and Switzerland. In fact, this is the geographical sample of countries participating in EU cross-border cooperation (henceforth, CBC) programmes (European Commission, 2016).

While absolute numbers of interviewees are relatively limited, ranging from 300 in Portugal to 4,410 in Germany, it is worth stressing that the interviewed sample has been selected only among citizens of border areas directly involved in CBC activities, and therefore knowledgeable about the possible limitations and obstacles associated to this type of actions. As mentioned above, the main advantage of the use of a broad measure is to allow our analyses to account for all possible legal and administrative barriers hampering regional growth, without entering into a detailed definition of such barriers. On the other hand, limitations are those typical of survey data, with a particular word of caution related to the difficulty in quantifying the strength of such barriers for the average interviewee. 
Since data are classified per country couple, we obtain a matrix of legal barrier where an average score ranging from 1 to 3 represents the average perceived legal and administrative barrier for a country couple. This prompts the generation of a pairwise asymmetric country blocks-matrix where each country couple (for instance, AT-DE) has constant values that can (and typically do) differ from the symmetric country couple (say, DE-AT).

\section{3 | Estimation results}

Table 2 shows the results of empirically estimating Equation 10. Results are organized along six columns, each based on heteroskedastic-robust OLS estimates of a specification including country fixed effects (columns (1)-(3)) or SARAR estimates (columns (4)-(6), also including country fixed effects). 2008-2013 value added growth is regressed against initial value added, the region's settlement structure, and the regional growth factors described in Section 4.2, and used also in Capello, Caragliu, and Fratesi (2017). Columns differ in that while the first and the fourth presents the estimation of Equation 10 with geographical spillovers alone, the second, third, fifth, and sixth columns also include the interactions of the latter with the degree of openness, and the degree of openness and legal barriers, respectively.

Across all models, some control variables are found to be always positively and significantly associated to regional growth, such as human capital and product innovation, while others negatively affect regional economic performance (such as a more urbanized settlement structure - not surprisingly, since cities have been most directly affected by the economic contraction taking place over the observed time frame; see e.g. Capello, Caragliu, \& Fratesi, 2015).

As for demand spillovers, they are always correlated with regional growth, although in the first specification statistical significance is only marginally below the usual $10 \%$ threshold.

The main result of these estimates is shown in columns (2) and (3). While in column (2) demand spillovers interacted with the openness indicator are found to be positively and significantly associated to regional economic growth, their interaction with the legal barrier is negatively and significantly correlated with regional performance. All in all, results hint at a hampering role played by institutional barriers in European regional growth. ${ }^{8}$

A number of consistency checks have also been performed to verify the robustness of our findings. VIF across the different regressors averages 3; multicollinearity seems in general not to be a major problem. However, as often the case in the empirical literature involving multiple interactions, the last and most important parameter of interest (the interaction between demand spillovers, degree of openness, and legal barriers) does reach a VIF of 11. In this case, we looked for the factor driving this result; in the end, the estimate coefficient is still significant, which testifies for the strength of the identified result (in fact, multicollinearity causes an increase in the standard error of the estimated parameter, which can be obnoxious only if the estimated parameter itself is not large enough). Given that the legal and administrative barriers are here estimated on the basis of country couples data, the clear suspect is the set of dummy variables. Once these are dropped from the estimates, VIF of the interaction terms drops to 1.52. Since estimated dummies are of minor interest in this paper, we believe this to be safe evidence that multicollinearity is not an issue in these estimates.

We also tested for spatial autocorrelation in the residuals and find that, as testified by Moran's I tests, there is some minor (in absolute terms), although significant spatial autocorrelation left in our estimates. Conservatively, we

\footnotetext{
${ }^{8}$ As a further robustness check we also replaced the great circle distance used to calculate demand spillovers with binary and economic distance, the former calculated with a 5 arcminutes distance band, the latter on the basis of the initial value added. Our main findings are all in all robust to these consistency checks. In the first case (binary weight matrix), the demand spillovers ${ }^{*}$ degree of openness estimated parameter is equal to 0.04 (not significant at the standard significance levels), but the demand spillovers * degree of openness * legal barrier is again negative, equal to -0.07 , and significant at the 95 per cent confidence level. In the case of the economic weight matrix, the demand spillovers * degree of openness estimated parameter is equal to 0.11 , the demand spillovers * degree of openness * legal barrier is again negative, equal to -0.11 , and both are only marginally insignificant ( $p$-value equal to 0.12 and 0.108 , respectively).
} 
TABLE 2 Empirical estimates of Equation 10

\begin{tabular}{|c|c|c|c|c|c|c|}
\hline \multicolumn{7}{|c|}{ Dependent variable: $2008-2013$ growth of GVA } \\
\hline Model & (1) & $(2)$ & (3) & (4) & (5) & (6) \\
\hline Constant term & $\begin{array}{l}0.10 \\
(0.13)\end{array}$ & $\begin{array}{l}0.19^{* *} \\
(0.09)\end{array}$ & $\begin{array}{l}0.20^{* *} \\
(0.09)\end{array}$ & $\begin{array}{l}0.15^{*} \\
(0.08)\end{array}$ & $\begin{array}{l}0.15^{*} \\
(0.08)\end{array}$ & $\begin{array}{l}0.15^{*} \\
(0.08)\end{array}$ \\
\hline Initial value added (log) & $\begin{array}{l}-0.02 \\
(0.00)\end{array}$ & $\begin{array}{l}-0.02 \\
(0.00)\end{array}$ & $\begin{array}{l}-0.03 \\
(0.00)\end{array}$ & $\begin{array}{l}-0.00 \\
(0.00)\end{array}$ & $\begin{array}{l}-0.00 \\
(0.00)\end{array}$ & $\begin{array}{l}-0.00 \\
(0.00)\end{array}$ \\
\hline Agglomerated regions & $\begin{array}{l}-0.08^{*} \\
(0.01)\end{array}$ & $\begin{array}{l}-0.07^{* *} \\
(0.01)\end{array}$ & $\begin{array}{l}-0.07^{*} \\
(0.01)\end{array}$ & $\begin{array}{l}-0.01^{*} \\
(0.01)\end{array}$ & $\begin{array}{l}-0.01^{*} \\
(0.01)\end{array}$ & $\begin{array}{l}-0.01^{*} \\
(0.01)\end{array}$ \\
\hline Urban regions & $\begin{array}{l}-0.06^{* *} \\
(0.01)\end{array}$ & $\begin{array}{l}-0.06^{* *} \\
(0.01)\end{array}$ & $\begin{array}{l}-0.06^{* *} \\
(0.01)\end{array}$ & $\begin{array}{l}-0.01^{* *} \\
(0.01)\end{array}$ & $\begin{array}{l}-0.01^{* *} \\
(0.01)\end{array}$ & $\begin{array}{l}-0.01^{* *} \\
(0.01)\end{array}$ \\
\hline Urbanisation economies & $\begin{array}{l}0.02 \\
(0.00)\end{array}$ & $\begin{array}{l}0.04 \\
(0.00)\end{array}$ & $\begin{array}{l}0.04 \\
(0.00)\end{array}$ & $\begin{array}{l}0.00 \\
(0.00)\end{array}$ & $\begin{array}{l}0.00 \\
(0.00)\end{array}$ & $\begin{array}{l}0.00 \\
(0.00)\end{array}$ \\
\hline Accessibility & $\begin{array}{l}-0.14^{* * *} \\
(0.01)\end{array}$ & $\begin{array}{l}-0.16^{* * *} \\
(0.01)\end{array}$ & $\begin{array}{l}-0.17^{* * *} \\
(0.01)\end{array}$ & $\begin{array}{l}-0.05^{* * *} \\
(0.01)\end{array}$ & $\begin{array}{l}-0.05^{* * *} \\
(0.01)\end{array}$ & $\begin{array}{l}-0.05^{* * *} \\
(0.01)\end{array}$ \\
\hline Saving propensity & $\begin{array}{l}-0.02 \\
(0.01)\end{array}$ & $\begin{array}{l}-0.01 \\
(0.01)\end{array}$ & $\begin{array}{l}-0.01 \\
(0.01)\end{array}$ & $\begin{array}{l}-0.01 \\
(0.01)\end{array}$ & $\begin{array}{l}-0.01 \\
(0.01)\end{array}$ & $\begin{array}{l}-0.01 \\
(0.01)\end{array}$ \\
\hline Trust & $\begin{array}{l}0.01 \\
(0.01)\end{array}$ & $\begin{array}{l}0.01 \\
(0.01)\end{array}$ & $\begin{array}{l}0.01 \\
(0.01)\end{array}$ & $\begin{array}{l}0.00 \\
(0.01)\end{array}$ & $\begin{array}{l}0.00 \\
(0.01)\end{array}$ & $\begin{array}{l}0.00 \\
(0.01)\end{array}$ \\
\hline Human capital & $\begin{array}{l}0.13^{* * *} \\
(0.05)\end{array}$ & $\begin{array}{l}0.15^{* * *} \\
(0.05)\end{array}$ & $\begin{array}{l}0.15^{* * *} \\
(0.05)\end{array}$ & $\begin{array}{l}0.16^{* * *} \\
(0.04)\end{array}$ & $\begin{array}{l}0.16^{* * *} \\
(0.04)\end{array}$ & $\begin{array}{l}0.15^{* * *} \\
(0.04)\end{array}$ \\
\hline Knowledge & $\begin{array}{l}0.00 \\
(0.00)\end{array}$ & $\begin{array}{l}-0.01 \\
(0.01)\end{array}$ & $\begin{array}{l}-0.01 \\
(0.00)\end{array}$ & $\begin{array}{l}-0.00 \\
(0.00)\end{array}$ & $\begin{array}{l}-0.00 \\
(0.00)\end{array}$ & $\begin{array}{l}-0.00 \\
(0.00)\end{array}$ \\
\hline Product innovation & $\begin{array}{l}0.04^{*} \\
(0.00)\end{array}$ & $\begin{array}{l}0.05^{* *} \\
(0.00)\end{array}$ & $\begin{array}{l}0.05^{*} \\
(0.00)\end{array}$ & $\begin{array}{l}0.01^{*} \\
(0.00)\end{array}$ & $\begin{array}{l}0.01^{*} \\
(0.00)\end{array}$ & $\begin{array}{l}0.00 \\
(0.00)\end{array}$ \\
\hline Productive capacity & $\begin{array}{l}-0.04^{*} \\
(0.02)\end{array}$ & $\begin{array}{l}-0.05^{*} \\
(0.02)\end{array}$ & $\begin{array}{l}-0.05^{* *} \\
(0.02)\end{array}$ & $\begin{array}{l}-0.05^{* *} \\
(0.02)\end{array}$ & $\begin{array}{l}-0.05^{* *} \\
(0.02)\end{array}$ & $\begin{array}{l}-0.05^{* *} \\
(0.02)\end{array}$ \\
\hline Demand spillovers & $\begin{array}{l}0.08 \\
(0.00)\end{array}$ & - & - & $\begin{array}{l}0.01^{* *} \\
(0.00)\end{array}$ & - & - \\
\hline $\begin{array}{l}\text { Demand spillovers * degree of openness } \\
\text { (share of manufacturing) }\end{array}$ & - & $\begin{array}{l}0.13^{* *} \\
(0.00)\end{array}$ & $\begin{array}{l}0.25^{* * *} \\
(0.00)\end{array}$ & - & $\begin{array}{l}0.01^{* *} \\
(0.00)\end{array}$ & $\begin{array}{l}0.01^{* *} \\
(0.00)\end{array}$ \\
\hline $\begin{array}{l}\text { Demand spillovers * degree of openness * } \\
\text { legal barrier }\end{array}$ & - & - & $\begin{array}{l}-0.20^{* * *} \\
(0.00)\end{array}$ & - & - & $\begin{array}{l}-0.02^{* * *} \\
(0.00)\end{array}$ \\
\hline Heteroskedasticity-robust standard errors & Yes & Yes & Yes & Yes & Yes & Yes \\
\hline Country fixed effects & Yes & Yes & Yes & Yes & Yes & Yes \\
\hline Number of obs. & 1,069 & 1,068 & 1,068 & 1,068 & 1,068 & 1,068 \\
\hline $\mathrm{R}^{2}$ & 0.57 & 0.58 & 0.58 & - & - & - \\
\hline Estimation method & OLS & OLS & OLS & SARAR & SARAR & SARAR \\
\hline Average VIF & 3.02 & 2.33 & 3.00 & - & - & - \\
\hline Hausman test (OLS vs. IV ${ }^{\S}$ ) & - & - & $\begin{array}{l}0.68 \\
(0.41)\end{array}$ & - & - & - \\
\hline Moran's I & 0.0087 & 0.0083 & $0.0079^{* * *}$ & - & - & - \\
\hline Pseudo $\mathrm{p}$-value & 0.00 & 0.00 & 0.00 & - & - & - \\
\hline Lambda & - & - & - & $\begin{array}{l}0.14^{*} \\
(0.07)\end{array}$ & $\begin{array}{l}0.14^{* *} \\
(0.07)\end{array}$ & $\begin{array}{l}0.17^{* * *} \\
(0.07)\end{array}$ \\
\hline Rho & - & - & - & $\begin{array}{l}0.13 \\
(0.11)\end{array}$ & $\begin{array}{l}0.13 \\
(0.11)\end{array}$ & $\begin{array}{l}0.09 \\
(0.11)\end{array}$ \\
\hline Joint F-test of significance & $33.76^{* * *}$ & $26.83^{* * *}$ & $24.71^{* * *}$ & - & - & - \\
\hline
\end{tabular}

Notes: Heteroscedasticity-robust standard errors in brackets. OLS parameters are standardised. *, ${ }^{* *}$, and ${ }^{* * *}$ imply significance at the $90 \%, 95 \%$, and $99 \%$ confidence level, respectively.

${ }^{\S}$ The endogeneity Hausman test has been performed on the triple interaction term Demand spillovers * Degree of openness * Legal barrier term. 
re-estimated the three models with a SARAR specification. ${ }^{9}$ Results of this battery of estimates are reported in Table 2, columns (4)-(6). Our main findings hold exactly as with OLS estimates, with the same sign and significance (although parameters estimated with the SARAR specification are not standardized and hence cannot be compared to the previous results, columns (1)-(3) in the same table).

Lastly, while these empirical tests are not meant to address causality, we did perform the classical Durbin-WuHausman test for the endogeneity of the demand spillovers - degree of openness - legal barrier term. The Durbin-Wu-Hausman test starts from the null hypothesis that OLS and IV estimates are equivalent (Baum, Schaffer, \& Stillman, 2003). If this $\mathrm{H}_{0}$ cannot be rejected (which is the case as shown in Table 2), then there is no need for instrumenting the variable of interest. While this first test is clearly not fully solving the issue of endogeneity, we believe that, in addition to the use of time-lagged explanatory variables, endogeneity should be a minor problem if any - in these results.

\section{I SPATIAL EFFECTS OF INCREASED LEGAL AND ADMINISTRATIVE BARRIERS}

The previous section empirically verified the model set out in Section 3, and provided an assessment of the intensity of the impact of legal and administrative barriers on regional growth through a demand effect linked the reduction of export spillovers. On the basis of these findings, this Section presents an analysis of the impact of new barriers arising between European Countries. In particular, we focus on the possible increase in legal and administrative barriers, as measured in Section 4.

The aim of this section is to present a simulation of what the regional demand-side costs of dismembering the EU due to new legal and administrative barriers between countries could be. This simulation requires some assumptions on what could happen once these barriers increase to the maximum level between each country couple. This implies testing what happens in case European regions, rather than having the current intensity of legal and administrative barriers, face an increase to the maximum possible level. ${ }^{10}$

The impact of the newly increase barriers on each European region $i$ is calculated, consistently with Equation 8 , as in the following Equation 13. Equation 13 shows that the impact is a positive function of parameter $\mu$ (whose estimate has been presented in Section 4), of the regional degree of openness $\vartheta_{i}$ (proxied by regional manufacturing specialization), of the distance-weighted income of other regions $\left(\frac{Y_{j}}{d_{i j}}\right)$, discounted by the arising of a new bilateral barrier $\left(\Delta b_{i j}\right)$ :

Barrier impact $_{i}=\mu \vartheta_{i} \Sigma_{j} \Delta b_{i j} Y_{j}$,

The new legal and administrative barrier, in this simulation, will be the difference between the maximum possible level on the variable scale and the actual level of the barrier. With this approach, all EU regions will experience an increase of legal and administrative barriers with respect to other countries; however, this increase will be larger in absolute terms for those regions currently benefiting from relatively low barriers. By increasing barriers in all countries, we actually simulate the effects of EU dismembering, in the case that Brexit is followed up by other countries.

\footnotetext{
${ }^{9}$ More specifically, spatial autocorrelation is addressed on the basis of a SARAR model in the specification of Arraiz, Drukker, Kelejian, and Prucha (2010) and Drukker, Egger, and Prucha (2013). The model reported in columns (4)-(6) therefore includes a weighted average of regional value added growth (the spatial lag component), as a right-hand-side variable; thus, it allows us to verify whether disturbances depend on a weighted average of other units' disturbances.

${ }^{10} \mathrm{Clearly}$, some region couple already reached the maximum level; as a consequence, while representing the (negative) benchmark, in this simulation the values in these region couples do not change.
} 
Results of this simulation are presented in two maps which show the impact in terms of losses of GDP growth due demand spillovers' limitations which forcedly follow an increase of legal and administrative barriers (Figure 3). In particular, Figure 3a presents the GDP growth losses in absolute terms, while Figure 3b displays the same result in relative terms, namely, with the colour of each region representing the impact with respect to the Country average (set to 100). Using both maps, it is easier to detect which EU NUTS3 regions would be more affected in the case of the EU dismembering, and separatist policies would be implemented in each country.

Figure 3 a shows that impacts would not be homogeneous among countries and regions, and that four spatial effects, all linked to the parameters of the theoretical model, emerge with evidence.

In particular, it clearly emerges that countries more affected would be those in central Europe, especially those among the original six EU members which also had more time to strengthen their relationships (notably, France, Germany, Belgium, the Netherlands). However, results also show that the UK would also be negatively affected by this scenario, because of its proximity to, and its close relations with, the European core. More geographically peripheral countries, in particular Scandinavian and Iberian ones, and the Balkans, are in absolute terms less directly affected by GDP losses due to a reduction of demand spillovers.

At the regional scale, some features of the processes are clearly identifiable, especially with the joint use of the two maps showing the absolute and the relative effects, respectively, at the left and right-hand side of Figure 3). As expected, regions closer to the border are ceteris paribus more affected. This is evident in most countries, for instance France and Italy, but is not a deterministic feature as in other countries, such as Germany and the UK, this effect is in fact overcome by other effects, so that border regions are not always necessarily the most affected ones in absolute terms. On the contrary, the border effect is especially strong in Central and Eastern European countries, such as Poland, Czech Republic, Slovakia and Hungary. In these countries, increased barriers will be detrimental especially for regions which benefited more in the past from their EU accession because of their proximity to the EU borders.

(a) Absolute values

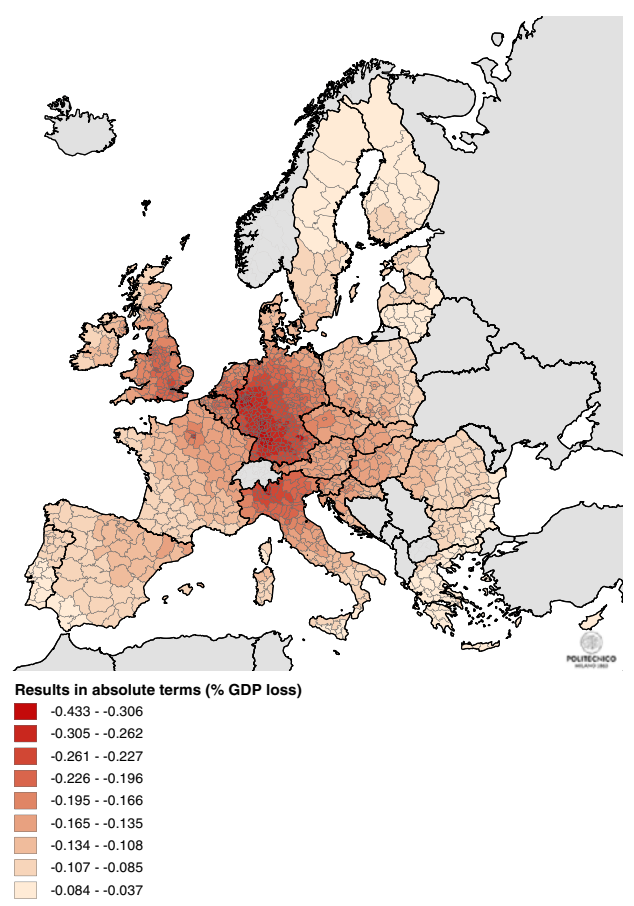

(b) Relative values (each region with respect to its nation)

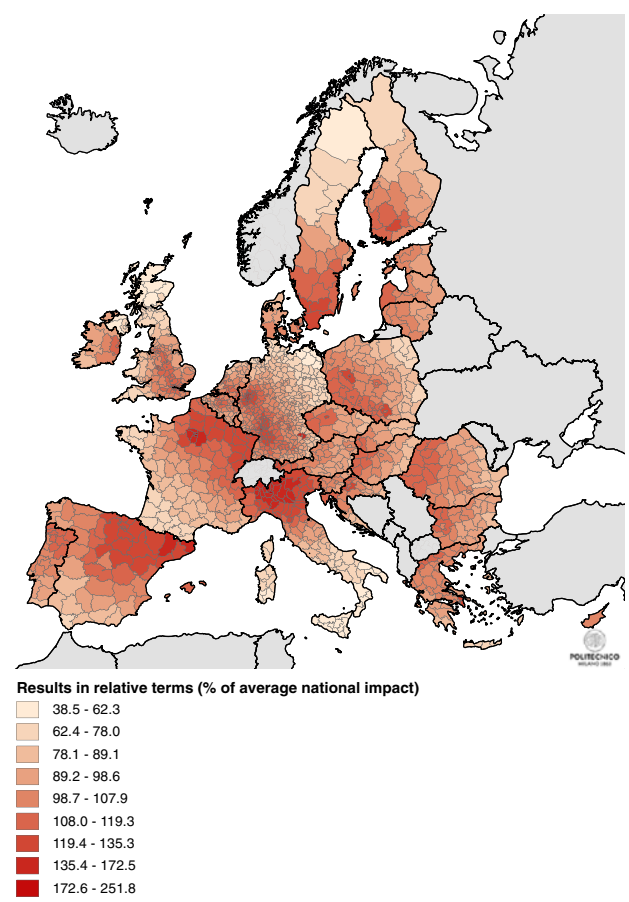

FIGURE 3 Loss of GDP due to the increase in legal and administrative barriers between European countries 
The effects of new legal and administrative barriers also show an agglomeration pattern. Ceteris paribus, more peripheral regions and less dense areas are less affected than central and dense ones. This suggests the presence of a centrality effect and a demand concentration effect, because regions which are more central and/or closer to other significant economies are more affected, as it was expected from the model. This is evident in Figure 3 for most countries, for example in France around Paris; in Germany, along the Rhine Valley; in the UK around the axis going from London to Liverpool through Birmingham and Manchester; but also in Greece, around Athens or Bulgaria and Romania around Sofia and Bucharest, respectively.

Finally, the degree of openness also matters, as evidenced by the higher values estimated for regions belonging to traditionally export-oriented manufacturing areas, such as the Third Italy or the Ruhr valley in Germany. This suggests that the increase of administrative barriers is subject to an exposure effect.

All in all, it looks like the newly augmented legal and administrative barriers will be damaging mostly regions in Western Germany, an area where all effects suggested by the model (and here empirically estimated) are simultaneously at play. In fact, these areas are highly accessible due to their centrality; are highly agglomerated as each region is very dense and close to other dense areas; are highly specialized in export manufacturing; and, finally, are very close to the border with France, Belgium and the Netherlands. The demand impact of dismembering the EU will on the contrary be lower for Bulgaria and Greece, two countries that are geographically peripheral and whose economies depend less on exports with respect to other EU countries.

\section{I CONCLUSIONS}

This paper highlighted the spatial effects that could occur in case other EU countries would follow the UK example, and decide to leave the EU, leading to its dismembering. Within all possible effects that may take place, the paper focused on the impacts that market size reductions would have on trade flows, in their turn due to the reinstatement of substantial legal and administrative barriers.

We theoretically modelled within a Keynesian framework the impact of such barriers on trade. Because these barriers would hamper demand spillovers that regions benefit from by being part of the Single Market, augmented legal and administrative barriers would cause four spatial effects: an exposure effect, due to the different openness of regions, a centrality effect, due to the different accessibility of regions in spatial terms, a demand concentration effect, due to the different closeness of regions to large trade partners and a border effect, due to the different distance of regions from the borders. Within the theoretical model set out in this paper, none of these effects is ex ante expected to prevail.

The paper then econometrically tested this theoretical model. Empirical results show that existing legal and administrative barriers between EU countries do generate demand spillover losses, which result in slower GDP growth. Econometric estimates also allow to give a value to the parameter which are theoretically derived from the model. However, it is important to acknowledge that endogeneity issues have not been fully tackled in this paper and results should be therefore interpreted with care, and possibly strengthened by robust testing and credible instruments. ${ }^{11}$

Based on these parameters, a simulation exercise was carried out, where barriers are strongly augmented among all EU countries. Results of this simulation show that demand spillovers decrease with different intensity in different regions. The centrality effect tends to prevail, because in Europe the geographic core and the most agglomerated areas tend to coincide; however, once this point is taken into account by measuring losses with respect to the country mean (thereby making the distance of each region with respect to the EU economic core more homogeneous), the other effects emerge more clearly.

Simulations suggest that the spatial impacts would be strongly heterogeneous among EU regions. Some rich areas in West Germany would in particular face the highest losses, because of the cumulative negative impacts due to the

\footnotetext{
${ }^{11}$ While the Durbin-Wu-Hausman test discussed in Section 4 suggests no need to resort on IV estimation, it must be acknowledged that the test does not ensure that endogeneity is fully solved. We would like to thank an anonymous reviewer for pointing at this issue.
} 
four different spatial effects. Europe's engine would therefore face stronger negative consequences, which would probably cause in the medium and long run an additional growth slowdown in the rest of Europe.

Our findings hint at a very relevant role played by inherently space-specific effects in shaping the impact of a EU dismembering, well beyond macroeconomic factors that are at a first sight first expected to channel such impacts. The creation of the Common Market and the EU has in fact enacted a number of changes in the way EU national economies interact with one another. National economies are now strongly interconnected, and our findings suggest that any attempt to break these linkages could not come without a cost, part of which is spatially very heterogeneous. In fact, these impacts occur well beyond areas where legal and administrative barriers are already relatively high, to impact also regions that so far gained the most from the creation of the EU.

Moreover, although presently at a merely speculative level, it can be argued that these effects could be at play even in the very short run, right after possible decisions to exit the EU would be made by countries other than the UK. The rational expectation channel (captured by a subjective nature of our variable "barrier") could in fact rapidly transfer such negative beliefs to firms and consumers, instantaneously decreasing trade flows, thus ultimately slowing down GDP growth.

Our research presents potential promising extensions along many directions. One line of research could be to address the impact of augmenting barriers within a macro-econometric regional growth model, which allows us to formally take account of the likely interactions between these newly augmented barriers and other regional growth factors, and to estimate the feed-back effects that the decrease in demand spillovers would generate on supply side elements fostering GDP growth. Another line of research relates the analysis of the spatially heterogeneous macroeconomic effects caused by the dismembering process, in general treated and analysed as space invariant.

This rich agenda needs to be quickly undertaken so that sound and evidence-based policy suggestions can follow suit, and political decisions can be fed with a clearer picture of what the likely consequences in the various scenarios could be.

\section{REFERENCES}

Arraiz, I., Drukker, D. M., Kelejian, H. H., \& Prucha, I. R. (2010). A spatial Cliff-Ord-type model with heteroskedastic innovations: Small and large sample results. Journal of Regional Science, 50, 592-614.

Bachtler, J., \& Downes, R. (1999). Regional policy in the transition countries: A comparative assessment. European Planning Studies, 7, 793-808.

Balassa, B. (1975). Trade creation and diversion in the European Common Market: An appraisal of the evidence. In B. Balassa (Ed.), European economic integration (pp. 79-118). Amsterdam: North-Holland.

Baum, C., Schaffer, M., \& Stillman, S. (2003). Instrumental variables and GMM: Estimation and testing. Stata Journal, 3, 1-31.

Becattini, G. (1990). The Marshallian industrial district as a socio-economic notion. In F. Pyke, G. Becattini, \& W. Sengenberger (Eds.), Industrial districts and inter-firm cooperation in Italy (pp. 37-51). Geneva: ILO.

Boltho, A., \& Eichengreen B. (2008). The economic impact of European integration. CEPR Discussion paper 6820.

Brakman, S., \& Van Marrewijk, C. (2017). A closer look at revealed comparative advantage: Gross-versus value-added trade flows. Papers in Regional Science, 96, 61-92.

Breinlich, H. (2006). The spatial income structure in the European Union: What role for economic geography? Journal of Economic Geography, 6, 593-617.

Camagni, R. (1991). Technological change, uncertainty and innovation networks: Towards a dynamic theory of economic space. In R. Camagni (Ed.), Innovation networks: Spatial perspectives (pp. 121-144). London: Belhaven-Pinter.

Camagni, R. (1992). Development scenarios and policy guidelines for the lagging regions in the 1990's. Regional Studies, 26, 361-374.

Camagni, R., \& Maillat, D. (Eds.) (2006). Milieux Innovateurs: Théorie et Politiques. Paris: Economica.

Camagni, R., \& Pompili, T. (1990). Competence, power and waves of urban development in the Italian city system. In P. Nijkamp (Ed.), Sustainability of urban systems: A cross-national evolutionary analysis of urban innovation (pp. 37-86). Aldershot: Avebury.

Camagni, R., Capello, R., Caragliu, A., \& Toppeta, A. (2017). Quantification of the effects of legal and administrative border obstacles in land border regions. Report for European Commission. 
Campos N., Corricelli F., \& Moretti L. (2014). Economic growth and political integration: synthetic counterfactual evidence from Europe. mimeo. IZA DP No. 8162. Retrieved 14 December 2017 from http://ftp.iza.org/dp8162.pdf

Capello, R. (2002). Urban rent and urban dynamics: The determinants of urban development in Italy. The Annals of Regional Science, 36, 593-611.

Capello, R. (2016). Regional economics (2nd ed.). London: Routledge.

Capello, R. (2017). Cohesion policies and the creation of a European identity: The role of territorial identity. Journal of Common Market Studies, https://doi.org/10.1111/jcms.12611

Capello, R., \& Fratesi, U. (2013). The service sector in the new globalization phase: Evidence from European regions. In J. R. Cuadrado-Roura (Ed.), Service industries and regions: Growth, location and regional effects (pp. 43-64). Berlin: Springer Verlag.

Capello, R., Fratesi, U., \& Resmini, L. (2011). Globalisation and regional growth in Europe: Past trends and scenarios. Berlin: Springer Verlag.

Capello, R., Caragliu, A., \& Fratesi, U. (2015). Spatial heterogeneity in the costs of the economic crisis in Europe: are cities sources of regional resilience? Journal of Economic Geography, 15, 951-972.

Capello, R., Caragliu, A., \& Fratesi, U. (2017). Measuring border effects in European cross-border regions. Regional Studies, https://doi.org/10.1080/00343404.2017.1364843

CEC (2001). Unity, solidarity, diversity for Europe, its people and its territory. Second report on economic and social cohesion. Brussels: CEC.

Cecchini, P., Jacquemin, A. P., Robinson, J., \& Catinat, M. (1988). The European Challenge: 1992. Aldershot: Wildwood House.

Dhingra, S., Ottaviano, G., Sampson, T., \& Van Reenen, J. (2016a). The consequences of Brexit for UK trade and living standards. In J. Van Reenen (Ed.), BREXIT 2016 - Policy analysis from the Centre for Economic Performance (pp. 12-23). http://cep.lse.ac.uk/pubs/download/brexit08_book.pdf

Dhingra, S., Ottaviano, G., Sampson, T., \& Van Reenen, J. (2016b). The impact of Brexit on foreign investment in the UK. In J. Van Reenen (Ed.), BREXIT 2016 - Policy analysis from the Centre for Economic Performance (pp. 24-33). URL: http://cep.Ise. ac.uk/pubs/download/brexit08_book.pdf

Dosi, G. (1982). Technological paradigms and technological trajectories. Research Policy, 3, 147-162.

Drukker, D. M., Egger, P., \& Prucha, I. R. (2013). On two-step estimation of a spatial autoregressive model with autoregressive disturbances and endogenous regressors. Econometric Reviews, 32, 686-733.

Dunne, J. (Ed.) (2015). Mapping the Cost of Non-Europe, 2014-19. European Added Value Unit, Directorate for Impact Assessment and European Added Value, Directorate-General for Parliamentary Research Services (EPRS), European Parliament, B-1047 Brussels. Retrieved 15 March 2017 from http://www.europarl.europa.eu/RegData/etudes/STUD/2015/ 536364/EPRS_STU(2015)536364_EN.pdf

European Commission (2016). Cross Border Cooperation. URL: https://ec.europa.eu/neighbourhood-enlargement/ neighbourhood/cross-border-cooperation_en

Gilly, J. P., \& Torre, A. (Eds.) (2000). Dynamiques de Proximité. Paris: L'Harmattan.

Godel, M. I., Harms, A., Jones, S., \& Mantovani, I. (2016). Reducing costs and barriers for businesses in the Single Market. European Parliament's Committee on Internal Market and Consumer Protection. Retrieved 15 March 2017 from http://www.europarl.europa.eu/RegData/etudes/STUD/2016/578966/IPOL_STU(2016)578966_EN.pdf

Head, K., \& Mayer, T. (2006). Regional wage and employment responses to market potential in the EU. Regional Science and Urban Economics, 36, 573-595.

Ilzkovitz, F., Dierx, A., Kovacs, V., \& Sousa, N. (2007). Steps towards a deeper economic integration: The internal market in the 21st century. Directorate General Economic and Financial Affairs (DG ECFIN), European Commission No 271. Retrieved 18 December 2017 from http://ec.europa.eu/economy_finance/publications/pages/publication784_en.pdf

Jensen, M. D., \& Snaith, H. (2016). When politics prevails: the political economy of a Brexit. Journal of European Public Policy, 23, 1302-1310.

Malmgren, H. B. (1961). Information expectation and the theory of the firm. Quarterly Journal of Economics, 75, 399-421.

Nelson, R., \& Winter, S. (1982). An evolutionary theory of economic change. Cambridge, MA: Harvard University Press.

Obstfeld, M., \& Rogoff, K. (2000). The six major puzzles in international macroeconomics: Is there a common cause? NBER Macroeconomics Annual, 15, 339-390.

Petrakos, G. (2000). The spatial impact of East-West integration in Europe. In G. Petrakos, G. Maier, \& G. Gorzelak (Eds.), Integration and transition in Europe (pp. 38-68). London: Routledge.

Petrakos, G., Rodriguez-Pos, A., \& Rovolis, A. (2005). Growth, integration, and regional disparities in the European Union. Environment and Planning A, 37, 1837-1855. 
Puga, D. (2002). European regional policies in light of recent location theories. Journal of Economic Geography, 2, $373-406$.

Quévit, M. (1992). The regional impact of the internal market: A comparative analysis of traditional industrial regions and lagging regions. Regional Studies, 26, 349-360.

Resmini, L. (2007). Regional patterns of industry location in transition countries: Does the economic integration with the EU matter? Regional Studies, 41, 747-764.

Roberts, J. (1989). The internationalisation of business service firms: A stages approach. The Service Industries Journal, 19(4), 68-88.

Scitovski, T. (1958). Economic theory and Western Europe integration. London: Allen and Unwin.

Simon, H. (1972). Theories of bounded rationality. In C. B. McGuire, \& R. Radner (Eds.), Decision and organization (pp. 161-186). North Holland, Amsterdam: Elsevier.

Storper, M. (1995). The resurgence of regional economies ten years later: The region of untraded interdependencies. European Urban and Regional Studies, 2, 191-221.

Thirlwall, A. P. (1974). Regional economic disparities and regional policy in the Common Market. Urban Studies, 11, 1-12.

Traistaru, I., Nijkamp, P., \& Resmini, L. (Eds.) (2003). The emerging economic geography in EU accession countries. Aldershot: Ashgate.

Van Reenen J. (Ed.) (2016). BREXIT 2016 - Policy analysis from the Centre for Economic Performance. URL: http://cep.lse.ac.uk/ pubs/download/brexit08_book.pdf

How to cite this article: Capello R, Caragliu A, Fratesi U. The regional costs of market size losses in a EU dismembering process. Pap Reg Sci. 2017;1-18. https://doi.org/10.1111/pirs.12347 